УДК 374.1

DOI: https://doi.org/10.35387/od.2(20).2021.51-63

\begin{tabular}{|c|c|}
\hline $\begin{array}{lrr}\text { Пуховська } & \text { Людмила } \\
\text { Прокопівна } & - & \text { доктор } \\
\text { педагогічних } & \text { наук, } & \text { профресор, } \\
\text { профресор кафредри фрілософрії та }\end{array}$ & $\begin{array}{l}\text { Puhovska Liudmyla - Doctor of } \\
\text { Pedagogical Sciences, Professor, } \\
\text { Professor of the Philosophy and } \\
\text { Adult Education Department of the }\end{array}$ \\
\hline $\begin{array}{l}\text { јсвіти дорослих Центрального } \\
\text { 'нституту } \\
\text { післядипломної }\end{array}$ & $\begin{array}{l}\text { Central Postgraduate Education } \\
\text { Institute of the State Institution of }\end{array}$ \\
\hline віти ДЗВО «Університет & Higher Education \\
\hline $\begin{array}{l}\text { енеджменту освіти» НАПН } \\
\text { країни }\end{array}$ & $\begin{array}{l}\text { Educational Management» } \\
\text { NAES of Ukraine }\end{array}$ \\
\hline
\end{tabular}

ORCID iD: http://orcid.org/0000-0002-0313-7761

E-mail: Puhovska@ukr.net

\title{
ЄВРОПЕЙСЬКІ СТРАТЕГІЇ, ПІДХОДИ І МОДЕЛІ РОЗВИТКУ ОСВІТИ ДОРОСЛИХ
}

\begin{abstract}
Анотація. У статті розкриваються європейські стратеаії розвитку френомену освіти дорослих в умовах відкритості та інтернаціоналізації освітньо-наукового простору. Автор наголошує на завданнях розбудови освіти і навчання дорослих як ефективного сектора в структурі иілісної системи освіти кожної країни. Характеризуються теорії освіти дорослих, які найбільш поширені у світі - андрагогічна, навчання на основі досвіду, трансорормаційна та розкриваються можливості щодо їх використання в контексті нових підходів до навчання фрахівців. Обгрунтовується думка про те, що нові підходи західних вчених до теоретичного осмислення освіти дорослих можна представити у вигляді системи концепцій, об'єднаних вихідним педагогічним контекстом - теорією освіти упродовж життя, з ї сучасним наголосом на дорослій половині людського життя після отримання основної освіти. У статті доводиться, що завдання переосмислення освіти і підготовки фахівців в XXI cm. в Україні і за кордоном актуалізує емпіричні теорії навчання, центральним концептом яких $\epsilon$ досвід. Автором аналізуються положення трансформаційного навчання, результатом впровадження якого в освітній процес може стати трансформація профресійного розвитку педагогів, особистісний розвиток $i$ підвищення рівня педагогічної майстерності педагогів. Виокремлюються базові ідеї трансорормаційної теорії навчання дорослих про те, що перспективні перетворення особистості мають три виміри: психологічний (зміни в розумінні себе), ціннісний (перегляд системи переконань) $i$ поведінковий (зміни в стилі життя). Робиться огляд сучасних успішних моделей професійного розвитку педагогів в зарубіжній практиці освіти модель «Школа профресійного розвитку» (Professional Development School PDS), клінічна модель (clinical model), модель навчання на робочому місці (work-based learning), модель навчання на базі проектів (project-based learning), модель навчання на основі реальних проблем (PBL), модель навчання на базі досвіду (experience-based learning systems - EBLS), матрична модель свідомої компетентності (matrix model of conscious competence). Зроблено висновок
\end{abstract}


про необхідність використання в Україні зарубіжних теоретичних надбань у сфрері освіти дорослих з метою вибудови максимально ефективного навчання на всіх етапах - від створення концепції до практичної реалізації; формування стратегій з урахуванням контексту навчання; використання педагогами технологій, які максимально відповідають контексту; профресійного розвитку педагогів як рефлексуючих практиків.

Ключові слова: європейські стратеаії; теорії освіти дорослих; моделі освіти дорослих; трансформація професійного розвитку; зарубіжний досвї.

\section{Puhovska Liudmyla}

\section{EUROPEAN STRATEGIES, APPROACHES AND MODELS FOR ADULT EDUCATION DEVELOPMENT}

Abstract. The article reveals the European strategies for developing the phenomenon of adult education under the conditions of open and international educational and scientific space. The author emphasizes the tasks for developing adult education and training as an efficient structure component in a holistic education system of each country. There are the most world-wide theories of adult education and their characteristics. They are androgical, experience-based learning, transformational and open opportunities for their use in new approaches to training. It is argued that new approaches of Western scholars to the theoretical understanding of adult education can be represented as a system of concepts united by the original pedagogical context - the theory of lifelong learning, with its modern emphasis on the adult half of human life after primary education. The article proves that the task of rethinking education and training in the XXI century in Ukraine and abroad actualizes empirical experience-centered learning theories. The author analyzes the provisions of transformational learning. Its implementation in the educational process can transform professional development of teachers, personal development and upskilling for teachers. The basic ideas of transformational theory for adult learning aimed at a personality's transformations have three dimensions: psychological (changes in self-understanding), value (revision of belief systems) and behavioral (changes in lifestyle). There is a review of modern successful models of professional development of teachers in foreign educational practice model. They are Professional Development School (PDS), clinical model, work-based learning model, project-based learning model (PBL), experience-based learning systems (EBLS) and matrix model of conscious competence. The conclusion is made about the need to use foreign theoretical achievements in the field of adult education of Ukraine. It will ensure building the most efficient learning at all stages - from concept to practical implementation; formation of learning context based strategies; use bestfor-context technologies and teachers' professional development as reflective practitioners.

Key words: European strategies; theories of adult education; models of adult education; transformation of professional development; foreign experience.

Постановка проблеми, її актуальність. Проблема дослідження полягає у вирішенні суперечності між необхідністю теоретичного аналізу і 
узагальнення змін, які проходять в освіті дорослих у світовому і європейському просторах, 3 одного боку, та у розробці нового концептуального змісту освіти і навчання дорослих Україні в умовах переосмислення освіти XXI століття - 3 іншого.

Аналіз актуальних досліджень і публікацій. Обґрунтуванню теоретичних засад освіти дорослих присвячено праці багатьох вітчизняних вчених: О. Аніщенко, С. Архіпової, М. Вовк, О. Волярської, М. Ільяхової, В. Кременя, Л. Лук'янової, Н. Ничкало, О. Огієнко, В. Олійника, Л. Петренко, О. Рассказової, С. Сисоєвої та ін. Значна увага надавалась проблемам професійного розвитку фахівців в системі післядипломної освіти, зокрема, це вчені Я. Бельмаз, Н. Сегеда, Т. Баришнікова, Н. Морозова, О. Вакуліна, Г. Ігнатьєва, Т. Сорочан, М. Скрипник, 3. Рябова та ін. Провідні концепції в галузі професійної педагогіки розкрито в працях С. Амеліна, Н. Волкова, В. Радкевич, А. Сущенко, Т. Сущенко та ін. Проте на сучасному етапі мова йде про кардинальні зміни ролі, функцій і місця освіти і навчання дорослих в системі життєдіяльності суспільства.

Виклад основного матеріалу. Освіта дорослих залишається одним із провідних стратегічних пріоритетів у країнах Європейської спільноти з початку XXI століття, коли освіта була визначена Лісабонською декларацією ключовим ресурсом розвитку. Сьогодні, як ніколи, освіта та навчання дорослих (ALE) можуть відігравати вирішальну роль у формуванні майбутнього Європи. Проблема у тому, що у вітчизняній і зарубіжній педагогічній теорії освіта дорослих традиційно розглядалося як додаткова до отриманої раніше головної освіти. Історично і донедавна освіта дорослих виконувала переважно компенсуючу функцію. У сучасних умовах ситуація змінюється: освіта дорослих стає однією з провідних форм соціальної активності людини і одною із найважливіших сфер життєдіяльності суспільства. Ці зміни декларуються в провідних міжнародних документах, рекомендаціях міжнародних організацій та об'єднань (офіційних, освітніх, професійних тощо). Так, у «Маніфесті освіти дорослих для XXI століття», (розробленого в рамках програми Євросоюзу ERASMUS), зазначається, що вона може впливати на такі сфери діяльності як: 1) активне громадянство, демократія та участь; 2) навички, які потрібні для життя і покращення його якості; 3) соціальна єдність, рівність і справедливість; 4) зайнятість і поширення цифрової інформації; 5) міграція і демографічні виміри; 6) стійкість (надання достатньої інформації і умов для формування нових життєвих принципів і підходів); 7) європейська політика (Manifesto for Adult Learning in the 21st Century: The Power and Joy of Learning, 2019).

На реалізацію нових завдань обґрунтовуються Рекомендації розробляються спеціальні програми різного рівня, створюються електронні навчальні платформи, такі як платформа для навчання дорослих в Європі (COUNCIL RECOMMENDATION, 2011, 2016; European Commission). В останнє десятиріччя навчання дорослих стає пріоритетом європейської інтеграції на період до 2020 року. Розвиток цих процесів стимулювався низкою Рекомендацій Ради Європейської Комісії з різних аспектів освіти 
дорослих. Зокрема, тоді вперше констатувалось, що навчання дорослих $є$ найслабшою ланкою в національних системах навчання протягом усього життя. Для створення ефективного сектору освіти і навчання дорослих, в Європейському порядку денному плануються такі дії: розширення можливостей для всіх дорослих отримати доступ до гнучкого високоякісного навчання в будь-який момент їхнього життя; розробка нових підходів до освіти дорослих, орієнтованих на результати навчання; підвищення обізнаності про те, що навчання - це праця всього життя; розробка ефективних систем і систем орієнтації протягом усього життя для підтвердження неформального та інформального навчання» (COUNCIL RECOMMENDATION, 2011).

Водночас «термін дії» Стратегії «Європа-2020» (2011-2020 рр.) завершився. Цей фракт зумовлює занепокоєність європейських громадських і професійних об'єднань, педагогічної громадськості з приводу того, що в новій достроковій стратегії ЄС започатковані ініціативи можуть не отримати подальшого розвитку. Адже пандемія відкинула Європейський Союз, як і весь світ, на поріг нової економічної кризи. У відповідь на ці побоювання нещодавно Європейська мережа Еврідіка (Euridice) - інституція ЄС, опублікувала розгорнуту доповідь «Про сучасний стан освіти і підготовки дорослих: вибудовуємо інклюзивні шляхи до умінь і кваліфікацій (European Commission/EACLA/Eurydice, 2021), створену за тематичним принципом на базі національних доповідей країн-членів. Нашу увагу привернули розділи, присвячені теоретичному осмисленню і обґрунтуванню нових теоретичних підходів до навчання дорослого населення в Європі. Зокрема, це проблеми гнучкого навчання і визнання результатів навчання, конструювання модульних програм і кваліфікацій, індивідуального навчання дорослих тощо.

Підходи західних вчених до теоретичного осмислення освіти дорослих можна представити у вигляді системи концепцій, об'єднаних вихідним педагогічним контекстом - теорією освіти упродовж життя, $з$ їі сучасним наголосом на дорослій половині людського життя, після отримання основної освіти. Передусім йдеться про концепції «подальшої освіти», «подовженої освіти», «неформальної освіти», «поновлюваної освіти», «освіти дорослих», громадської освіти/освіти в громаді», «організації, яка навчається», «суспільства, яке навчається», «суспільства, заснованого на знаннях» та ін. Як зазначають українські й зарубіжні дослідники різних аспектів теорії і практики освіти дорослих (Д. Бартон, А. Мітіна, О. Волярська, П. Кенді, Л. Лук'янова, О. Огієнко, Л. Петренко, Н. Савинова, К. Тастінг, М. Ілляхова), кожна з цих теорій при деякій їх подібності в цілому по-різному тлумачать освіту дорослих. Узагальнювально-інтегративними можна вважати концепції «суспільства, яке навчається» і «суспільства, заснованого на знаннях» 3 описом освітньої ситуації та суттєвих зв'язків в соціально-економічній структурі сучасного суспільства. Концепція формування суспільства нового типу з'явилася на рубежі століть, коли інформація стала набувати якісно нової форми - гармонізованих знань. Важливого значення, окрім знань типу «як 
діяти», набули знання типу «як співіснувати», які стали гармонізовувати внутрішні й зовнішні суперечності суспільства. Ця фрорма суспільства дозволила людині перейти до масового виробництва нових знань 3 використанням потужних інструментів, якими є ІКТ. Суспільство такого типу набуло принципово нових вимірів - соціального, етнічного, політичного тощо. Невід'ємними його компонентами стали нові міждисциплінарні знання, які продукують наукові та суспільні інститути, підготовка високоякісного людського капіталу, що здійснює освіта, створення багатств на базі економіки знань, в кінцевому рахунку, формування на цій основі інтегрального вектора розвитку суспільства, спрямованого на підвищення якості та безпеки життя всіх його членів.

Провідними у науковому обґрунтуванні освіти і навчання дорослих $€$ емпіричні теорії навчання, центральним концептом яких $є$ досвід. Окрім цього поняття концептуальний апарат емпіричних теорій включає: «соціальний контекст навчання», «самоспрямованість навчання дорослих», «рефлексивну практику», «практичну спрямованість навчання», «перспективу часу», тобто, негайне використання результатів навчання тощо. Зауважимо, що більшість досліджень щодо сутності, принципів, методик навчання були розроблені в контексті навчання школярів у рамках формальної освіти. Дослідження навчання дорослих і розвиток андрагогіки як науки почали здійснюватися на противагу дитячій педагогіці. Нині про особливості навчання дорослих йдеться в багатьох наукових дослідженнях, відправною точкою яких $€$ теорії навчання. Вчені прагнуть показати, як вони сприяють одна одній і доповнюють розуміння того, як навчаються дорослі. Переважно обґрунтовуються такі ключові ідеї:

- Дорослі мають власну мотивацію з опертям на свої знання і досвід; вони «вписують» навчання у свої цілі, пов'язуючи з їхнім реальним життям, практикою і ролями, які вони виконують поза навчальним закладом.

- Дорослі мають прагнення до самоспрямування і самостійного навчання; навчання ініціює той, хто навчається, і одна з функцій вчителя полягає в тому, щоб забезпечити ефективне середовище, в якому може відбуватися навчання.

- Дорослі здатні вчитися, синтезуючи різні стилі навчання і формуючи свій власний стиль навчання, вивчати процеси власного навчання, отримуючи користь від обговорення та роздумів про це.

- Навчання $€$ характеристикою всіх видів діяльності в реальному житті, де люди виконують різні ролі й навчаються на практиці. Навчання може «з'єднати» ці види діяльності, дозволяючи дорослим, які навчаються, розвивати нові форми ерудиції і компетентності.

- Дорослі рефлексують, спираючись на свій досвід. Рефлексивне навчання виникає, коли люди стикаються з проблемами у своєму реальному житті та шукають шляхи їх вирішення.

- Рефлексивне навчання $€$ унікальним для кожної людини, оскільки воно виникає через складність її власного досвіду. Велика частина навчання $€$ випадковою та пов'язаною з тим, хто навчається: його 
неможливо спланувати заздалегідь. Хоча є речі, які можна зробити, щоб заохотити рефрлексивне експериментальне навчання, проте немає обґрунтованого набору кроків, які можна було б виконати, щоб гарантувати, що цей процес відбудеться. Таке навчання дозволяє людям реорганізувати досвід і «побачити» ситуацію по-новому. Отже, навчання дорослих потенційно трансформує як особистість, так і ії соціальні характеристики (Tusting, Barton, 2003).

Важливо зазначити, що у ранніх моделях навчання, розроблених у США та Європі, навчання розглядалося переважно як феномен особистості. Тому серед найбільш поширених теорій, які було покладено в основу різних моделей навчання, виокремлено такі: біхевіоризм, когнітивізм, когнітивний конструктивізм, психологія розвитку та ін. Одночасно в країнах Радянського Союзу і пізніше - пострадянського просторі, розвивалося розуміння феномена навчання як форми соціальної участі (соціокультурна психологія: теорії діяльності та ситуативного пізнання тощо).

Новітні дослідження в Європі та США стали імпульсом для розвитку сучасних теорій навчання дорослих. Серед них чільне місце належить таким теоріям: андрогогічній (the theory of andragogy); навчанню на основі досвіду (experience learning theory), трансфрормаційному навчанню (transformative learning theory). В Україні найбільш відомою i поширеною $є$ андрагогічна теорія з широким обґрунтуванням особливостей навчання дорослих. Водночас в умовах посилення практичної орієнтації освіти і науки важливого значення набуває теорія навчання на основі досвіду, яка стверджує, що сутність навчання дорослих в осмислюванні їх практичного досвіду. Ця теорія не $є$ абсолютно новою для вітчизняних вчених. Адже в різні часи вітчизняні дослідники звертались до «теорії експериментального навчання», «теорії емпіричного навчання», «експіріенс-теорії» тощо. Проте, глобальне визнання й поширення динамічної, цілісної моделі процесу навчання на основі досвіду, безумовно пов'язане з прийняттям світовою спільнотою стратегії освіти упродовж життя. Іїї актуальність обґрунтовується зосередженістю знань на інформації, яка має безпосереднє відношення до реальних професійних ситуацій, розвитком цінних якостей і умінь, корисних упродовж всього життя (лідерські якості, навики командної роботи і комунікації, готовність до адекватного відбору сучасних педагогічних технологій, досвід вирішення проблем тощо). Як наголошує ії засновник Д. Колб, теорія навчання на засадах досвіду базується на напрацюваннях видатних вчених XX століття, зокрема, В. Джеймса, Д. Дьюї, К. Левіна, М. П. Фоллет, Ж. Піаже, Л. Виготського, К. Юнга, П. Фрейре, К. Роджерса та ін., які у своїх теоріях навчання й розвитку людини відводили центральну роль досвіду (Kolb, E.Y., Kolb, D. A., Passarelli, Sharma, 2014).

У сучасних зарубіжних системах педагогічної освіти використовується низка моделей навчання на основі досвіду, які лише частково отримали оцінку і поширення у системі педагогічної освіти в Україні. Найбільш успішними, на думку дослідників, $є$ такі: модель «Школа 
професійного розвитку» (Professional Development School - PDS), клінічна модель (clinical model), модель навчання на робочому місці (work-based learning), модель навчання на базі проектів (project-based learning), модель навчання на основі реальних проблем (PBL), модель навчання на базі досвіду (experience - based learning systems - EBLS), матрична модель свідомої компетентності (matrix model of conscious competence). Як підкреслюють зарубіжні експерти, ефективність цих моделей залежить від практичної спрямованості змісту освіти, що відповідає потребам суспільства у фахівцях не тільки з високим професійним потенціалом, але й здатних до розкриття цього потенціалу в реальних умовах професійної діяльності.

У контексті модернізаційних процесів у сфері професійної підготовки й профресійного розвитку педагогів в Україні особливо актуальними залишаються дослідження Д. Колба, який науково обґрунтував чотири стадії циклу емпіричного навчання: практичний досвід; рефрлексивне спостереження; абстрактна концептуалізація; активне експериментування. Чотири рівні навчання також описуються М. Бродвеллом в його матричній моделі свідомої компетентності, яка реалізується в системі освіти США ще з 70-х pp. XX століття. Значним потенціалом для професійного розвитку педагогів характеризується модель навчання на базі проектів, запропонована Е. Морганом. В Україні напрацьовано конструктивний досвід ії використання, проте розширення цієї практики здатне забезпечити новий якісний рівень професійного i особистого розвитку педагогів, зокрема, у вітчизняних закладах післядипломної освіти з відповідною продуманою адаптацією при моделюванні освітнього процесу як у традиційних, так і в інноваційних закладах післядипломної освіти (таких, як Український віртуальний університет післядипломної освіти).

Трансформаційна теорія навчання дорослих (transformative theory of adult learning) вважається однією із основних у навчанні дорослих. Вона набула цього статусу завдяки працям Дж. Мезірова, К. Кінга, П. Крентона, Дж. Діркса, Р. Бойда, К. Тейлора, Моріса Ж. Еліаса та інших (Eliase, Rockefeller, Goleman, Gullotta, Sluyter, 1997). Існують різні інтерпретації в розумінні того, що називають трансформаційним навчанням, проте кожна відкриває нові аспекти і межі розуміння цього феномена. Частина вчених визначають трансформаційну теорію навчання як розширення свідомості через трансформацію базової картини світу і характеристик своєї індивідуальності (Моріс Ж. Еліас). Деякі - тлумачать цей явище як глибокі усвідомлення, які змінюють життєві настанови і виводять нашу свідомість на новий рівень в процесі «накладання» нових знань на старий досвід, або розгляду старих уявлень в новому світлі в ході навчання дорослих. При цьому досліджується перетин між навчанням та розвитком 3 опорою на конструктивізм, теорії навчання дорослих та експериментальне навчання (Е.В.Тейлор, С. Марієнау, М. Фідлер). У головного архітектора трансформаційного навчання Дж. Мезірова відправним пунктом трансформаційної теорії $€$ твердження, що під час навчання у зрілому віці, 
не просто набуваються знання, а з'являється нова інтерпретація попереднього досвіду, а це, у свою чергу, слугує орієнтиром для майбутніх дій і відкриває можливості для входження дорослого в громадське життя у новій якості. За Дж. Мезіровим, навчання - це осмислення дорослим свого досвіду, тому для усвідомлення цього досвіду дорослому здебільшого потрібно внести зміни в якісь із його переконань або поглядів. Зміна точки зору - це лінза, через яку дорослий усвідомлює світ, це ключ до трансформаційного навчання. Процес і результат трансформаційного навчання $\epsilon$ розвитком, тобто здатністю критично реагувати. Саме результат і змінена думка дорослого підносить його до нового щабля розвитку (Mezirow, 1991).

Трансформаційна теорія навчання дорослих базується на ідеї про те, що перспективні перетворення особистості мають три виміри: психологічний (зміни в розумінні себе), ціннісний (перегляд системи переконань) і поведінковий (зміни в стилі життя). Набір переконань дорослого трансформується за допомогою критичного переосмислення припущень, на яких будуються його інтерпретації, думки, звички розумової діяльності й точка зору тощо. Дорослий може стати «критично реслективним» до своїх або чужих припущень, коли він навчається вирішувати проблеми інструментально, або коли приймає участь у комунікативному навчанні, бере участь у вирішенні проблеми (об'єктивний рефрейминг), або самостійно критично оцінює свої власні ідеї та переконання (суб'єктивний рефрейминг). Саморефлексія може призвести до значних особистісних трансформацій, тому саме саморефлексія має вирішальне значення в трансформації перспективи (Eliase, Rockefeller, Goleman, Gullotta, Sluyter, 1997).

Упродовж двох десятиліть Концепція трансформації професійного розвитку в освіті знаходиться в центрі дискусій, метою яких $є$ генерування цікавих і складних ідей та відкритті нових перспектив, зокрема, в професійному розвитку педагогів. Як зазначає А. Свеннен - редактор міжнародного журналу «Professional Development in Education (PDiE), центральними у дискусіях щодо майбутнього PDiE в сучасних умовах $\epsilon$ «трансформаційна освіта» і «критична рефлексія». Незважаючи на те, що поняття «трансформаційна освіта» $€$ не зовсім новим, останнім часом воно все частіше фрігурує у статтях та у матеріалах міжнародних науковопрактичних конференцій 3 осучасненим і поглибленим змістовим наповненням. Компаративні дослідження доводять, що ключові поняття, які вживаються в теорії і практиці світової освіти, мають своє конкретне значення в національному, культурному та освітньому контексті і що ми повинні це усвідомлювати, коли пишемо для міжнародної аудиторії та коли читаємо статті авторів з педагогічних культур, відмінних від нашої власної.

Відмінності між педагогічними культурами породжують цікаві та різні тлумачення того, що означає бути «трансформаційним». У цілому ж вчені схиляються до того, що поняття «трансформація» $є$ в синонімічному ряду з поміркованим поняттям «зміни», будучи сучасним кроком вперед в умовах загострення потреби в ідеалах та суспільних цінностях. Тому 
«трансформаційна освіта» проектується як бажаний стан освіти. Наукові пошуки в цьому напрямі активізувались на початку XXI ст., коли сформувався запит на моделювання освіти, включаючи професійний розвиток педагогів. Наприклад, у роботі Е. Кеннеді (2005) описується три цілі професійного навчання, в яких учителі мають все більшу свободу вибору: передача, перехід, трансформація. За Е. Кеннеді, характерними для трансформаційних моделей професійного навчання $€$ професійна автономія та усвідомлення проблем управління на всіх рівнях. Вона стверджує, що перетворюючі практики включають моделі передачі, перехідних досліджень та досліджень педагогічних дій, які можуть збалансовано підтримувати трансформацію навчання та виховання (Kennedy, 2005). Внесок цієї дослідниці в порівняльне дослідження моделей професійного розвитку вчителів (ПРВ) полягає в обґрунтуванні рамкової структури, побудованої на основі ключових характеристик окремих моделей ПРВ. Рамка містить дев'ять ключових моделей, які потім класифікуються залежно від їхньої здатності підтримувати професійну автономію та трансформаційну практику, а саме: навчальна модель (training model); так звана модель винагороди (award-bearing model), зокрема, отримання певного диплома; модель дефіциту (deficit model); каскадна модель (cascad model); модель, що базується на стандартах (standards-based model); модель коучингу/наставництва (coaching/mentoring model); модель спільноти практики (community of practice model); модель дослідження діяльності (педагогічної) (action research model); трансформаційна модель (transformative model).

Звичайно, це лише один із класифікаторів, обґрунтованих вченими, які предметно досліджують процес професійного розвитку вчителів. У різних національних контекстах рік від року зростає кількість досліджень, які в умовах стрімких змін розвивають нові підходи до професійного розвитку вчителів із урахуванням світових напрацювань. В умовах пандемії більшість моделей потребують доопрацювання, оскільки людство зіткнулось 3 проблемою навчання в контексті швидких технологічних і соціальних змін, зокрема, у сфері онлайн- та дистанційної освіти. Ці моделі мають посилювати аргументи щодо гнучкості підходів до навчання та надання освітніх послуг. Вчені наголошують, що успіх у навчанні дорослих забезпечується завдяки діалектичній взаємодії соціальних, ситуативних та індивідуальних факторів. Тобто, до уваги беруться контекст, цілі та практика кожного дорослого, який навчається.

Вважаємо за доцільне привернути увагу до дослідження українських науковців, яке проводиться в рамках науково-дослідної роботи з теми «Трансформація професійного розвитку педагогічних і науковопедагогічних працівників в умовах відкритого університету післядипломної освіти» (Університет менеджменту освіти НАПН України). Дослідники акцентують увагу на моделях професійного розвитку педагогів, які гіпотетично можуть вплинути на трансформацію розвитку педагогів в умовах відкритої освіти. Частково до таких віднесено: модель поетапно орієнтованої освіти педагога; модель соціального партнерства у розвитку 
професійної компетентності фахівців; позиційну модель із подальшим розвитком фахівців в умовах відкритої освіти та ін. (Петренко, Романова, Пуховська, Султанова, Олешко, 2020).

Висновки і перспективи подальших досліджень. Теорії освіти і навчання дорослих - це не простий набір ідей, концепцій і понять стосовно особливостей навчання дорослих людей, включаючи їх професійний розвиток. Необхідність їх використання зумовлена низкою причин: 1) теорії допомагають вибудовувати максимально ефективне навчання на всіх етапах - від створення концепції до практичної реалізації; 2) теорії лежать в основі формування стратегій з урахуванням реального контексту навчання; 3) теорії необхідні для використання технологій, які максимально відповідають стратегіям навчання; 4) знання теорій важливе для застосування стратегій, які враховують сучасні особливості навчання: цифрові технології і мобільність тощо. I хоча в сучасному суспільстві посилюються антисцієнтичні рухи і настрої, в цілому наука сприймається як одна із вищих цінностей цивілізації. Для трансформації професійного розвитку педагогів в Україні необхідні комплексні концепції і моделі, які поєднують в собі традиції та інновації: традиційне - це стрижень, а інноваційне - це живильне середовище для розвитку.

\section{Список використаних джерел}

COUNCIL RECOMMENDATION of 19 December 2016 on Upskilling Pathways: New Opportunities for Adults. (2016/ C484/01). Official Journal of the European Union, URL:

https://eur-lex.europa.eu/legalcontent/EN/TXT/?uri=OJ\%3AJOC_2016_484_R_0001

COUNCIL RECOMMENDATION of 28 June 2011 on policies to reduce early school leaving (2011/C 191/01). Official Journal of the European Union. URL: https://eur-lex.europa.eu/legal-

content/EN/ALL/?uri=CELEX\%3A32011H0701\%2801\%29

Eliase, M., Rockefeller, E., Goleman, D., Gullotta, T., \& Sluyter, D. [et.al.] (1997). Promoting Social and Emotional Learning: Guidelines for Educators. Association for Supervision and Curriculum Development. Alexandria, Virginia, USA. URL: https://earlylearningfocus.org/wpcontent/uploads/2019/12/promoting-social-and-emotional-learning-1.pdf

European Commission. EPALE-Electronic Platform for Adult Learning in Europe. URL: https://epale.ec.europa.eu/en

European Commission/EACLA/Eurydice (2021). Adult education and training in Europe: Building inclusive pathways to skills and qualifications. Eurydice Report. Luxembourg: Publication Office of European Union. URL: https://eacea.ec.europa.eu/national-

policies/eurydice/sites/default/files/adult_education_and_training_in_europ e_2020_21.pdf

Kennedy, $\bar{A}$. (2005) Models of Continuing Professional Development: a framework for analysis. Journal of In-service Education, 31(2). 235-250. URL: https://www.tandfonline.com/doi/pdf/10.1080/13674580500200277

Kolb, E.Y., Kolb, D. A., Passarelli, A., Sharma, G. (2014). On Becoming an Experiential Educator: The Educator Role Profile. Simulation \& Gamin, 45 
(2), 204-234. DOI: $10.1177 / 1046878114534383$

Manifesto for Adult Learning in the 21st Century: The Power and Joy of Learning. (2019). European Association for the Education of Adults (EAEA). URL: https://eaea.org/our-work/influencing-policy/manifesto-for-adult-learning-inthe-21st-century/

Mezirow, J. (1991). Transformative dimensions of adult learning / J. Mezirow. - San Francisco: Jossey-bass, URL: https://journals.sagepub.com/doi/abs/10.1177/074171369204200309

Tusting, K., \& Barton D. (2003). Models of adult learning: a literature review of models applicable to Skills for Life. London: National Research and Development Centre for Adult Literacy and Numeracy (NRDC). URL: https://dera.ioe.ac.uk/22486/1/doc 2768.pdf

Петренко, Л., Романова, Г., Пуховська, Л., Султанова, Л., \& Олешко, П. (2020). Моделі неперервного профресійного розвитку педагогічних і науковопедагогічних працівників у контексті відкритої освіти / Професійний розвиток фахівців в умовах цифрового суспільства: сучасні тренди: Матеріали науково-практичної конференції з міжнародною участю 12 13 листопада 2020. Житомир: Житомирський державний університет імені Франка, 243-250.

\section{References (translated and transliterated)}

COUNCIL RECOMMENDATION of 19 December 2016 on Upskilling Pathways: New Opportunities for Adults. (2016/ C484/01). Official Journal of the European Union, URL: https://eur-lex.europa.eu/legalcontent/EN/TXT/?uri=OJ\%3AJOC_2016_484_R_0001 [in English].

COUNCIL RECOMMENDATION of 28 June 2011 on policies to reduce early school leaving (2011/C 191/01). Official Journal of the European Union. URL: https://eur-lex.europa.eu/legalcontent/EN/ALL/?uri=CELEX\%3A32011H0701\%2801\%29 [in English].

Eliase, M., Rockefeller, E., Goleman, D., Gullotta, T., Sluyter, D., [et.al.] (1997). Promoting Social and Emotional Learning: Guidelines for Educators. Association for Supervision and Curriculum Development. Alexandria, Virginia, USA. URL: https://earlylearningfocus.org/wpcontent/uploads/2019/12/promoting-social-and-emotional-learning-1.pdf [in English].

European Commission. EPALE-Electronic Platform for Adult Learning in Europe. URL: https://epale.ec.europa.eu/en [in English].

European Commission/EACLA/Eurydice (2021). Adult education and training in Europe: Building inclusive pathways to skills and qualifications. Eurydice Report. Luxembourg: Publication Office of European Union. URL: https://eacea.ec.europa.eu/nationalpolicies/eurydice/sites/default/files/adult_education_and_training_in_europ e_2020_21.pdf [in English].

Kennedy, A. (2005) Models of Continuing Professional Development: a framework for analysis. Journal of In-service Education, 31(2). 235-250. URL: https://www.tandfonline.com/doi/pdf/10.1080/13674580500200277 [in English].

Kolb, E.Y., Kolb, D. A., Passarelli, A., Sharma, G. (2014). On Becoming an Experiential Educator: The Educator Role Profile. Simulation \& Gamin, 45 
(2), 204-234. DOI: 10.1177/1046878114534383 [in English].

Manifesto for Adult Learning in the 21st Century: The Power and Joy of Learning. (2019). European Association for the Education of Adults (EAEA). URL: https://eaea.org/our-work/influencing-policy/manifesto-for-adult-learning-inthe-21st-century/ [in English].

Mezirow, J. (1991). Transformative dimensions of adult learning. San Francisco: Jossey-bass,

URL:

https://journals.sagepub.com/doi/abs/10.1177/074171369204200309 [in English].

Petrenko, L., Romanova, G., Puhovska, L., Sultanova, L., \& Oleshko, P. (2020). Modeli neperervnoho profesiynoho rozvytku pedahohichnykh i naukovopedahohichnykh pratsivnykiv u konteksti vidkrytoyi osvity [Models of continuous professional development of pedagogical and scientificpedagogical specialists within the context of an open education]. Profesiynyy rozvytok fakhivtsiv $v$ umovakh tsyfrovoho suspil'stva: suchasni trendy: Materialy naukovo-praktychnoyi konferentsiyi z mizhnarodnoyu uchastyu 12-13 lystopada 2020. Zhytomyr: Zhytomyrs'kyy derzhavnyy universytet imeni Franka, 243-250 [in Ukrainian].

Tusting, K., Barton, D. (2003). Models of adult learning: a literature review of models applicable to Skills for Life. London: National Research and Development Centre for Adult Literacy and Numeracy (NRDC). URL: https://dera.ioe.ac.uk/22486/1/doc_2768.pdf [in English]. 